Mentha asiatica L. Многолетняя трава с длинными и короткими корневищами; высота достигает 0,30-0,40 м. Растет у арыков, каналов, возле саев и на влажных землях. Лекарственное.

Stachys palustris L. Многолетняя трава с короткими корневищами; высота достигает 0,30-0,60 м, распространено в тихо-текущих саях, озерах, возле арыков, каналов. Лекарственное.

$$
* * *
$$

1. Флора Узбекистана. - Ташкент, I-VI том, 1941-1963.

2. Определитель растений Средней Азии. - Ташкент, I-X том, 1965-1993.

3. Кокин К.А. Экология высших водных растений. М.: Изд-во Моск. ун-та, 1982. - 160 с.

4. Черепанов С.К. Сосудистые растения России и сопредельных государств (в пределах бывшего СССР). - Москва, 1995. 556 с.

5. Пратов О.П., Набиев М.М. Современные системы высших растений Узбекистана. - Ташкент, 2007. $62 \mathrm{c}$.

6. Белавская А.П. К методике изучения водной растительности // Бот. журн. - 1979. - Т. 64, № 1. - С. 32-41.

7. Катанская В.М. Методика исследования высшей водной растительности // Жизнь пресных вод СССР. - М., Л.: Изд-во АН СССР, 1956. - Т. 4, ч. 1. - С. 160-182.

8. Лапиров А.Г. Экологические группы растение водоемов. // Гидроботаника: методологии и методы. Материалы школы по гидроботаники. - Борок, 2003. С. 5-22

9. Лисицына Л.И. Гербаризация водных растений, оформление коллекций // Гидроботаника: методология, методы: Материалы школы по гидроботанике- Рыбинск, 2003. - С. 49-55.

10. ПапченковВ.Г. О классификации растений водоемов и водотоков. // Гидроботаника: методологии и методы. Материалы школы по гидроботаники. - Борок, 2003. С. 23-26.

\title{
Alizada Gulnar Aziz \\ Mites of Azerbaijan belonging to the species of Abrolophus (Actinedida: Erythraeidae)
}

Azerbaijan State Pedagogical University

(Azerbaijan)

doi:10.18411/spc-22-07-2019-05

idsp: sciencepublic-22-07-2019-05

Keywords: Azerbaijan, eritreid mites, Abrolophus species, predators, larvae, ectoparasites

Abrolophus Berlese, 1891 species are the typical species of the subfamily of Abrolophinae of the family of Erythraeidae. These species have cosmopolitan organism. Deutonymph and imagoes are predators, and the heteromorphic larvae are the ectoparasites of the arthropods that inhabit in the land areas. Also the plants are observed. Some species of the species of Abrolophus, for example Abrolophus longicollis, are the predators which their larvae inhabit freely. Some types of the species inhabited in the supra-littoral zone or in the upper borders of the eulittoral zone and in the rocky coasts of the estuary $[3,7]$.

115 species include to the species of Abrolophus. Only larvae are observed in 37 species of them. Only post-larval stages have been found in 70 species. The larvae, as well as, post-larval stages are known in only 3 species [6].

8 species of the mites of the species of Abrolophus are found in the Greater Caucasus Region, in Azerbaijan. It should be noted that these species of the mites are the effective cleaners of the sucking pests in the clover fields of Shamkir, in the vineyards of Ismayilli district in Azerbaijan, and in the oak forests (with Georgian oaks) of the low mountains of the Greater Caucasus [1,2]. There is short information about these species.

1. Abrolophus artemisiae (Schrank, 1803)

Material: Baku, artificial-forest massive, the floor of the pine trees, 1 adult individual, collected in 1986, 31 May (collected by O.Aslanov). 
Abrolophus artemisiae species are new for the Caucasian fauna.

Spreading area: Europe; Southern Caucasus (Azerbaijan) [4, 5].

2. $\quad$ Abrolophus miniatus (Hermann, 1804)

Material: Khizi district, Garabulagchay, plant-filled, plants, one female adult individual, on 26 August, 2017; Khizi district, Bakhishli village, paliurus-field, paliurus, 2 adult individuals, on 26 August, 2017; Khizi district, Aladash chain, forest-field area, plants, one female adult individual, on 15 September, 2018; Qakh district, Gashgachay village, hornbeam-peanut forest, plants, two female individuals, on $30 \mathrm{July,} \mathrm{2018;} \mathrm{Quba} \mathrm{district,} \mathrm{Ispik}$ village, peanut forest, moss, one female individual, on 5 August, 2018; Qabala district, Qamarvan kəndi, hornbeam forest, plants, 1 adult individual, on 30 September, 2018, were collected.

Abrolophus miniatus species are new for the Caucasian fauna.

Spreading area: Europe; Caucasus: Azerbaijan; North-Western Africa (Algeria); Island of Greenland $[4,5]$.

3. Abrolophus crassitarsus (Schweizer, 1951)

Material: Zagatala district, essential-oil sovkhoz-plant, tea plantation, tea bush, 1 adult individual, on 12 August, 2017; Khizi district, Bakhishli village, oak forest (with Georgian oak), grasses, 1 adult individual, on 26 August, 2017; Khizi district, Bakhishli village, oak forest (with Georgian oak), plants, 1 male individual, on 26 August, 2017; Khizi district, Bakhishli village, oak forest, umbrella tree, 5 adult individuals, on 26 August, 2017; Quba district, Jimi village, oak forest (with eastern oak), plants, 5 adult individuals, on 5 August, 2018; Ismayilli district, Lahij village, forest, plants, 3 adult individuals, on 2 September, 2018; Ismayilli district, Basqal village, hornbeam forest, plants, 2 adult individuals, on 2 September, 2018; Khizi district, Bakhishli village, arid thin forest (with Pyrus salicifolia), Pyrus salicifolia, 2 adult individual, on 1 July, 2018; Shabran district, Arablar village, semidesert, plants, 2 adult individuals, on 25 June, 2019; Shamakhi district, Dadagunash village, oak forest (with Georgian oak), plants, 11 adult individuals, on 17 June, 2019; Shamakhi district, arid thin forest (with Pyrus salicifolia), plants, 2 adult individuals, on 17 June, 2019, were collected.

Abrolophus crassitarsus species are new for the Caucasian fauna.

Spreading area: Central Europe; Southern Caucasus (Azerbaijan) [4, 5].

4. $\quad$ Abrolophus rhopalicus (C.L.Koch, 1837)

Material: Shamakhi district, Chukhuryurd village, grass-field area, plants, 3 female individuals, on 15 June, 2018, was collected.

These species are the indicator of the landscape of the forest-field area.

Abrolophus rhopalicus species are new for the Caucasian.

Spreading area: Europe; Southern Caucasu (Azerbaijan) [4, 5].

5. $\quad$ Abrolophus passerinii (Berlese, 1904)

Material: Absheron district, Jeyranbatan village, artificial forest massive, mint, 1 adult individual, on 20 July, 1985 (collected by O.Aslanov); Khizi district, Altiagaj village, forest, grasses, 1 adult individual, 3 larvae, on 26 May, 2011 (collected by O.Aslanov); Khizi district, Bakhishli village, oak forest (with Georgian oak), grasses, 1 adult individual, on 26 August, 2017, were collected.

Abrolophus passerinii species are new for the Caucasian fauna.

Spreading area: Island of Ireland, Central (Poland) and Southern (Italy) Europe; Southern Caucasus (Azerbaijan) [4, 5].

6. Abrolophus strojnyi Gabrys, 1992

Material: Khizi district, Yarimja village, oak forest, plants, 1 adult individual, on 20 July, 2012 (collected by O.Aslanov); Qakh district, Ilisu village, juniper growing, juniper, 3 adult individuals, on 5 June, 2013 (collected by O.Aslanov); Zagatala district, Jar village, hornbeam forest, plants, 4 adult individuals, on 30 July, 2018, were collected.

A.strojnyi is the indicator of the mountain-forest zone. 
Abrolophus strojnyi species are new for the Caucasian fauna. $[4,5]$.

Spreading area: Central Europe (Poland), Hungary; Southern Caucasus (Azerbaijan)

7. Abrolophus norvegicus (Thor, 1900)

Material: Qusar district, Kuzun village, sub-alpine birch forest, Radde birch, 4 adult individuals, on 4 August, 2018; Ismayilli district, Tirjan village, maple forest (with marvellous maple), plant, 1 adult individual, on 2 September, 2018, were collected. Also 1 adult individual of these species was found in black-clover field, in Shamkir district, Ashagi Seyfali village, on 25 August, 1985. It is an effective cleaner of the sucking pests of the blackclover in the black-clover fields of Shamkir district.

These species are the indicator of the mountain-forest zone.

Abrolophus norvegicus species are new for the Caucasian fauna.

Spreading area: Europe; Caucasus: Azerbaijan; Turkey [4, 5].

8. Abrolophus quisquiliarus (Hermann, 1804)

Material: Lerik district, Qosmalian village, rocks, 1 adult individual, on 28 June, 1985 (collected by X.Oliyev); Absheron peninsiula, Baku city, rocks, 1 female individual, on 10 May, 1985 (collected by O.Aslanov); Shabran district, Arablar village, forest-field, plants, 2 adult individuals, on 9 June, 2018; Khizi district, Bakhishli village, oak forest (with Georgian oak), plants, 2 adult individuals, on 1 July, 2018, were collected.

A.quisquiliarus is the indicator of the mountain-forest zone.

Abrolophus quisquiliarus species are new for the Caucasian fauna.

Spreading area: Europe; Caucasus: Azerbaijan $[4,5]$.

$$
* * *
$$

1. Асланов О.Х. К изучению хищных актинедидных клещей (Acariformes: Actinedida) виноградников Азербайджана, Works of Azerbaijan Zoologist Society, I volume (collection of the articles). Baku: "Science", 2008: 210-216

2. Асланов О.Х., Ализаде Г.А. Эритреиды (Acariformes: Actinedida: Erythraeidae) AMEA Works of Zoology Institute, 2018b, vol. 36, № 1: s. 129-134

3. Bartsch L et al. Süsswasserfauna von Mitteleuropa // Chelicerata Araneae, Acari, 2006. Band 7.2.1: p.p 6973

4. Beron P. Acarorum Catalogus I Acariformes: Calyptostomatoidea (Calyptostomatidae), Erythraeoidea (Smarididae, Erythraeidae). Pensoft and Nat. Mus. Natur. Hirst. Sofia: 2008: 271 p.p

5. https://fauna-eu.org/

6. Kamran M., Alatawi F.J. New species and new records of subfamily Abrolophinae (Acari: Erythraeidae) from Saudi Arabia // Systematic and Applied Acarology, 2015, 20 (2): p.p 195-202

7. Wohltmann A., Witte H., Olomski R. Organismal pattern causing high potential for adaptive radiation in Parasitengonae (Acari: Prostigmata). / Proceeding of the 10th international congress of Acarology. Melbourn, 2001: p.p 83-99 